\title{
PENGARUH METODE VAKT TERHADAP PENINGKATAN KEMAMPUAN MENGENAL BANGUN DATAR PADA ANAK CEREBRAL PALSY
}

\author{
Nia Sutisna, Ayi Rahmawati \\ Universitas Pendidikan Indonesia \\ niasutisna57@gmail.com
}

\begin{abstract}
This study was conducted to determine the effect of VACT method on increasing the ability to recognize flat waking in children with cerebral palsy. The VAKT method stands for Visual, Auditory, Kinesthetic and Tactile which is a method using all children's senses. The use of VAKT method in this study aims to improve the ability to recognize flat waking in children with cerebral palsy. Flat building material is the most basic concept in mathematics. Knowledge of forms is needed in various aspects of life. Based on this, cerebral palsy children in GaMus Early Childhood Education (Muslim Child Garage) experience problems in getting to know flat building. Cerebral palsy children have low intelligence (forgetfulness) and have a sense of inferiority. The method in this study is a single subject research or called Single Subject Research. The research design used is A-BA Design which has three phases, namely: A-1 (Baseline 1), B (Intervention), A-2 (Baseline 2). Based on the results of the study, it is known that the VAKT method can improve the ability of cerebral palsy children to recognize flat waking. It can be seen from the results of the mean level in each session an increase. From the mean level $A-1$ with a result of $33.33 \%$, the mean level of intervention with the mean level of $82.29 \%$ and the mean level of $A-2$ is $100 \%$. Based on the results of the acquisition, it can be concluded that the VAKT method can improve the ability to recognize flat waking in children with cerebral palsy.
\end{abstract}

Keywords: VAKT Method, Knowing Flat Build, Child with Cerebral Palsy

\begin{abstract}
Abstrak
Penelitian ini dilakukan untuk mengetahui pengaruh metode VAKT terhadap peningkatan kemampuan mengenal bangun datar pada anak cerebral palsy. Metode VAKT merupakan singkatan dari Visual, Auditori, Kinestetik dan Taktil yang merupakan metode dengan menggunakan seluruh indera anak. Penggunaan metode VAKT dalam penelitian ini bertujuan untuk meningkatkan kemampuan mengenal bangun datar pada anak cerebral palsy. Materi bangun datar merupakan konsep paling dasar dalam pelajaran matematika. Pengetahuan akan bentuk diperlukan dalam berbagai aspek dalam kehidupan. Berdasarkan hal itu anak cerebral palsy di PAUD GaMus (Garasi Anak Muslim) mengalami masalah dalam mengenal bangun datar. Anak cerebral palsy memiliki intelegensi yang rendah (pelupa) serta memiliki rasa rendah diri. Metode dalam penelitian ini adalah penelitian subjek tunggal atau disebut Single Subject Research. Desain penelitian yang digunakan adalah Desain A-B-A yang memiliki tiga fase yaitu A-1 (Baseline 1), B (Intervensi), A-2 (Baseline 2). Berdasarkan hasil penelitian diketahui bahwa metode VAKT dapat meningkatkan kemampuan anak cerebral palsy dalam mengenal bangun datar. Hal itu dapat dilihat dari hasil mean level pada setiap sesi terjadi peningkatan. Dari mean level A-1 dengan hasil $33,33 \%$, mean level intervensi dengan hasil mean level 82,29\% dan mean level A-2 $100 \%$.
\end{abstract}


Berdasarkan hasil perolehan itu dapat disimpulkan bahwa metode VAKT dapat meningkatkan kemampuan mengenal bangun datar pada anak cerebral palsy.

Kata Kunci: Metode VAKT, Mengenal Bangun Datar, Anak Cerebral Palsy

\section{A. PENDAhULUAN}

Pendidikan merupakan hal yang penting bagi manusia. Pendidikan dapat memberikan manfaat yang besar dalam memajukan suatu bangsa karena bisa mengangkat harkat dan martabat suatu Negara. Latief (dalam Tjasmini, 2016, hlm. 62) mendefiniskan cerebral palsy sebagai suatu sindroma dimana terdapat gangguan terutama system motorik, sikap tubuh, pergerakan otot, dengan atau tanpa keterbelakangn mental, dapat disertai gejala saraf lainnya yang disebabkan disfungsi otak sebelum perkembangannya sempurna. Selain itu pernyataan lain mengemukakan bahwa kelainan pada aspek gerak seringkali diikuti dengan kerusakan pada penglihatan, pendengaran, berbicara dan intelegensi (Bandhie, 2006, hlm. 126). Berdasarkan pernyataan yang sudah disampaikan, dapat disimpulkan bahwa anak cerebral palsy mengalami dampak langsung terhadap kondisi tubuh dan fisiknya. Baik kerusakan di motorik maupun intelegensinya, namun di sisi lain anak dengan hambatan cerebral palsy akan mengalami dampak tidak langsung, yang merupakan dampak cerebral palsy terhadap kondisi jiwanya. Bagaimana reaksi mereka terhadap kekurangan yang ada. Sesuai dengan pernyataan Salim (dalam Janah. 2017) bahwa "kelainan cerebral palsy dapat dinilai anak sebagai faktor penyebab kegagalan beruntun yang sering dialami anak $\mathrm{CP}$, akibatnya mereka memiliki harga diri yang rendah, pesimis terhadap kehidupan, perasaaan tidak mampu, dan lain sebagainya. Selain itu, pernyataan Salim (dalam Afriyanti, 2017) tentang anak cerebral palsy mengemukakan jika anak menilai orang lain memandang dirinya rendah, tidak mampu, dan anak bodoh, dampaknya anak akan menjadi tidak percaya pada kemampuan sendiri, penakut, ragu-ragu, rendah diri, dan lain-lain. Jika anak memiliki pengalaman yang selalu gagal dalam setiap aktivitas, maka dampaknya anak menjadi tidak kreatif, dan masih banyak lagi.

Berdasarkan studi pendahuluan yang dilakukan oleh peneliti yaitu terdapat anak cerebral palsy di PAUD GAMUS (Garasi Anak Muslim), di dalam kelas tersebut ada satu anak yang mengalami hambatan cerebral palsy, yang lainnya anak pada umumnya. Anak tersebut dalam kemampuan berpikir sedikit delay, namun anak masih bisa mengikuti instruksi dan pembelajaran dengan baik jika terus dibimbing. Peneliti melihat anak seringkali diejek oleh temantemannya. Anak terlihat murung dan raguragu ketika belajar, sehingga ketika proses pembelajaran anak sering tertinggal karena tidak percaya terhadap kemampuan dirinya sendiri. Terlihat ketika belajar mengenai bangun datar anak sedikit kesulitan sehingga harus terus diulang, dan anak tertinggal dibanding dengan anak-anak lainnya. Masalah lain yang sedang terjadi adalah anak belajar dalam lingkungan anak pada umumnya, tetapi pembelajaran dilakukan secara klasikal. Sehingga kebutuhan anak kurang terpenuhi, terlebih anak berada dalam masa pra operasional yang mengharuskan anak belajar secara kongkrit. Berdasarkan hal itu, dapat disimpulkan bahwa ada beberapa hal yang menjadi penyebab anak belum mampu dalam kemampuan mengenal bangun datar. Pertama karena memang dampak langsung dari hambatan cerebral palsy yang menyebabkan kerusakan pada intelegensinya sehingga sedikit delay. 
Kedua, disebabkan dampak tidak langsung adanya hambatan cerebral palsy yang menyebabkan kurangnya percaya diri pada anak karena berbeda dengan temantemannya, dan sering diejek oleh temantemannya sehingga anak merasa rendah diri dan merasa tidak mampu dalam belajar atau metode belajar yang kurang tepat.

Dengan demikian berdasarkan pernyataan yang sudah disampaikan dapat disimpulkan bahwa anak cerebral palsy mengalami dampak langsung dan tidak langsung terhadap dirinya. Dampak langsung yang ada selain mengalami hambatan dalam motoriknya, anak juga sedikit mengalami delay dalam kemampuan berpikirnya. Selain itu, anak kesulitan dalam belajar disebabkan tidak percaya diri dan merasa tidak mampu yang merupakan dampak tidak langsung akibat hambatan cerebral palsy. Ditambah dengan kurang tepatnya metode yang diberikan. Oleh karena itu anak memerlukan pembelajaran yang bisa memenuhi kebutuhannya, yaitu dalam kemampuan mengenal bangun datar. Bagaimana caranya agar anak termotivasi, semangat, percaya diri, lalu bagaimana caranya agar pembelajaran itu sesuai dengan usia perkembangannya.

Banyak sekali metode yang digunakan dalam kegiatan akademik ini. Kali ini peneliti ingin menggunakan metode VAKT (Visual, Auditori, Kinestetik, Taktil) dalam meningkatkan kemampuan mengenal bangun datar anak cerebal palsy. Asumsi yang melandasi metode ini adalah bahwa dalam pelaksanaan metode VAKT ini menggunakan seluruh indra. Metode ini menstimulasi seluruh indra anak. Diharapkan karena menggunakan seluruh indra kemampuan anak dalam mengenal bangun datar akan lebih mudah, menyenangkan dan sesuai dengan usia perkembangannya. Selain itu, metode VAKT ini memiliki prinsip menyenangkan, diharapkan anak akan semangat dalam mengenal bangun datar.

Munawir (2003, hlm. 95) menyatakan bahwa VAKT mendasarkan pada asumsi bahwa anak dapat belajar dengan baik apabila materi pengajaran disajikan dalam berbagai modalitas alat indera. Yaitu penglihatan (visual), auditory (pendengaran), kinesthetic (gerakan) dan tactile (perabaan). Metode VAKT merupakan singkatan dari Visual, Auditory, Kinesthetic, Tactile. Dalam pelaksaaan visual atau penglihatan anak akan diperlihatkan bentuk-bentuk bangun datar dengan media kongkrit bentuk bangun datar, selain itu anak mendengar nama-nama bangun datar. Setelah itu anak mencoba menggerakan jarinya untuk menelusuri gambar bentuk bangun datar tersebut dan ditambah dengan menggambar di udara, terakhir anak merasakan bagaimana bentuknya dengan melukis di pasir. Jika semua indra digunakan maka anak akan lebih mudah dalam mengenal bangun datar, banyak sekali metode atau media yang bisa digunakan dalam mengenalkan bangun datar, namun menurut peneliti metode ini memiliki prinsip menyenangkan sehingga anak akan tertarik untuk belajar selain itu, metode ini menggunakan seluruh indra anak.

Berdasarkan alasan dan asumsi yang sudah dijelaskan peneliti bermaksud untuk melakukan penelitian mengenai pengaruh metode VAKT (Visual, Auditori, Kinestetik, Takile) terhadap peningkatan kemampuan mengenal bangun datar pada anak cerebral palsy.

\section{B. KAJIAN LITERATUR}

1. Metode VAKT

Metode VAKT dikembangkan oleh Grace M. Fernald (Abdurrahman, 2003, hlm. 217) seorang psikolog pendidikan berkebangsaan Ameriak Serikat, oleh sebab itu metode VAKT dikenal juga sebagi metode Fernald. Metode VAKT 
merupakan metode pembelajaran multisensoris, pendekatan multisensori didasarkan pada asumsi bahawa anak akan belajar denga baik jika materi yang pembelajaran disajikan dalam berbabagi modalitas yaitu visual, auditori, kinestetik dan taktil (Munawir, 2005, hlm 168). Adapun penjabaran dari metode VAKT menurut Ni'mah (2015) adalah sebagai berikut:

a. Visual, modalitas ini mengakses citra visual, yang diciptakan maupun diingat, warna, hubungan ruang, potret mental, dan gambar menonjol dalam modalitas ini. Seseorang yang sangat visual mungkin bercirikan sebagai berikut:

1) Teratur, memperhatikan segala sesuatu, menjaga penampilan;

2) Mengingat dengan gambar, lebih suka membaca daripada dibacakan; dan

3) Membutuhkan gambaran dan tujuan menyeluruh dan menangkap detail, mengingat apa yang dilihat.

b. Auditorial, modalitas ini mengakses segala jenis bunyi dan kata diciptakan maupun diingat. Musik, nada, irama, rima, dialog, internal, dan suara menonjol. Seseorang yang sangat auditorial dapat dicirikan sebagai berikut:

a) Perhatiannya mudah terpecah;

b) Berbicara dengan pola berirama;

c) Belajar dengan cara mendengarkan, menggerkkan bibir/ bersuara saat membaca; dan

d) Berdialog secara internal dan eksternal.

c. Kinestetik, modalitas ini mengakses segala jenis gerak dan emosidiciptakan maupun diingat. Gerakan, koordinasi, irama, tanggapan emosional, dan kenyamanan fisik menonjol. Seseorang yang sangat kinestetik dicirikan sebagai:

1) Menyentuh orang dan berdiri berdekatan, banyak bergerak;

2) Belajar dengan melakukan, menunjuk tulisan saat membaca, menanggapi secara fisik; dan

3) Mengingat sambil berjalan dan melihat.

d. Taktil, modalitas ini mengakses segala jenis perabaan, menelusuri. Seseorang yang sangat tactile dicirikan sebagai:

1) Menuliskan huruf yang dipelajari;

2) Menerangkan dan menjelaskan di papan tulis; dan

3) Siswa memahami bunyi, bentuk dan cara membuat huruf dengan jalan menelusuri huruf yang di buat guru.

\section{Cerebral Palsy}

Salah satu permasalahan mengenai tumbuh kembang anak di lingkungan masyarakat adalah cerebral palsy, penyandang cerberal palsy akan terlihat pada ketidaksempurnaan fungsi mortorik pada anak. Dalam kajian Rudol CD (dalam Utomo 2013) insidensi dari cerebral palsy sebanyak 2 kasus per 1000 kelahiran hidup, dimana 5 dari 1000 anak memperlihatkan defisit motorik yang sesuai dengan cerebral palsy. Sekitar 50\% kasus termasuk ringan dan $10 \%$ termasuk kasus berat. $25 \%$ memiliki intelegensia $(I Q)$ rata-rata normal sementara $30 \%$ kasus menunjukan IQ di bawah 70, 35\% disertai kejang dan 50\% menunjukan gangguan bicara. Laki-laki lebih banyak dari perempuan $(1,4: 1,0)$, dengan ratarata $70 \%$ ada pada tipe spastik, $15 \%$ tipe atetotic, 5\% ataksia, dan sisanya campuran. 
Menurut Nur Azizah (2005) cerebral palsy dapat diartikan sebagai kelumpuhan pada otak yang menyebabkan tidak adanya kontrol otot, kelainan postur dan hambatan gerak. Sedangkan dalam kajian yang dilakukan oleh Mardiani dalam Ichsan (2014:4) cerebral palsy dapat menyebabkan gangguan sikap (postur), kontrol gerak, gangguan kekuatan otot yang biasanya disertai gangguan neorologik berupa kelumpuhan, spastic, gangguan basal ganglia, cerebellum, dan kelaianan mental (mental retardation). Untuk memahami lebih lanjut tentang CP maka berikut ini dikemukakan beberapa pengelompokan $\mathrm{CP}$ dalam kajian yang dilakukan oleh Hermanto (2006) sebagai berikut.

Pertama, menurut tipe gangguan geraknya. Gangguan dalam kelompok ini meliputi: Spastik; yaitu cerebral palsy jenis ini kelainannya terletak pada motor cortex. Penderitanya memiliki karakteristik fisik berupa kekakuan pada sebagian atau seluruh otot-ototnya. Kekakuan terjadi tidak hanya pada organ motorik anggota gerak tetapi juga pada organ-organ bicaranya; Kedua, Dyskenesia; yaitu umumnya ditandai dengan tidak adanya kontrol dan koordinasi gerak. Dalam kelompok ini meliputi dyskenesia jenis athetosis dan rigid. Athetosis, pada jenis ini tidak terdapat kekakuan, tetapi terjadi gerakan-gerakan tidak terkontrol (unvoluntary movement) yang terjadi sewaktu-waktu. Gerakan-gerakan tersebut tidak dapat dicegah sehingga mengganggu anak dalam setiap kegiatannya. Gerakan otomatis tersebut terjadi pada tangan, kaki, mata, bibir dan kepala. Gerakan tersebut tidak muncul saat anak dalam keadaan relaks atau tidur. Adapun pada bagian leher dan punggung biasanya terjadi hiperekstensi (ketegangan yang luar biasa); Ketiga, Hipotonia, ditandai dengan tidak adanya ketegangan pada otot. Anak biasanya tampak lemas, otot-ototnya tidak mampu merespon rangsang yang diberikan. Keempat, Tremor; Gejala yang tampak adalah adanya getaran-getaran ritmis yang terus-menerus pada tangan, mata atau kepala; Kelima, Ataxia, kelainannya terjadi pada cerebellum, sehingga penyandang kelainan ini akan mengalami gangguan pengendalian diri berkaitan dengan gangguan keseimbangan dan koordinasi; Keenam, tipe atau jenis campuran; maksudnya bahwa anak mengalami dua atau lebih kelainan, misal tremor dan rigid, ataxia dengan tremor, dan sebagainya. Tipe campuran tentu saja akan berdampak lebih parah bagi penderitanya dan akan mengaklami kesulitan dalam mengikuti proses pembelajaran di kelas.

3. Pembelajaran Anak Cerebral Palsy

Sebagaimana kita ketahui bahwa penyandang cerebral palsy, akibat adanya kelayuhan pada bagian otaknya, menyebabkan kemampuan gerak motorik, kemampuan koordinasinya mengalami banyak hambatan. Hambatan tersebut sesuai dengan jenis cerebral palsy yang disandangnya seperti terjadinya kekakuan, gerakan yang sulit dikendalikan, kejang-kejang dan sebagainya. Dampak yang ditimbulkan dari kondisi ini menyebabkan kemampuan penyandang cerebral palsy dalam hal akademik menjadi terhambat pula seperti untuk memvisualisasi atau mengekspresikan kegiatan akademik menjadi mengalami keterbatasan. Untuk itu dalam penyampaian materi pembelajaran selama proses pembelajaran tentu saja tidak dapat dilakukan secara langsung sebagaimana ketika mengajarkan suatu materi 
pelajaran kepada anak-anak pada umumnya.

Arah pembelajaran anak cerebral palsy diorientasikan pada adanya pengembangan dari berbagai hambatanhambatan yang dimiliki menjadi lebih baik. Seorang pakar yaitu Connor (1975) dalam Tjasmini (2016:66) mengemukakan bahwa sekurangkurangnya ada tujuh aspek yang perlu dikembangkan pada diri masing-masing anak cerebral palsy melalui pendidikan yaitu pengembangan intelektual dan akademik, membantu perkembangan fisik, meningkatkan perkembangan emosi dan penerimaan diri anak, mematangkan aspek sosial, mematangkan moral dan spiritual, meningkatkan ekspresi diri, dan mempersiapkan masa depan anak.

\section{METODOLOGI PENELITIAN}

Penelitian ini menggunakan Penelitian kuantitatif dengan menggunakan metode eksperimen dalam bentuk Single Subject Research yang bertujuan untuk mengetahui pengaruh dari perlakuan atau intervensi kepada subjek. Penelitian ini menggunakan menggunakan desain A-B-A.

Desain A-B-A memiliki tiga tahap yaitu baseline-1(A-1), Intervensi (B), dan juga baseline-2 (A-2). Penelitian pada baseline 1(A-1) adalah kondisi awal anak dalam kemampuan mengenal bangun datar yang meliputi kegiatan menyebutkan, menunjukkan dan mengelompokkan bangun datar sebelum pengukuran pada fase ini dilakukan sebanyak empat sesi sesi dengan durasi yang disesuaikan. Subjek dalam penelitian ini merupakan anak cerebral palsy di PAUD Garasi Anak Muslim. Kemampuan anak dalam mengenal bangun datar sangatlah kurang. Ada beberapa penyebab yang menjadi alasan kenapa anak bisa seperti itu. Pertama disebabkan karena delay yang disebabkan karena cerebral palsy. Yang kedua dikarenakan anak memiliki rendah diri yang tinggi karena merasa berbeda dengan teman yang lainnya. Teknik pengumpulan data ini adalah dengan menggunakan instrumen/tes. Alat pengumpulan data anak adalah dengan cara mencatat semua hasil data kemampuan mengenal bangun datar pada anak dan menghitung ke dalam bentuk persentase. Data analisis yang digunakan adalah analisis dalam kondisi dan analisis antar kondisi.

\section{HASIL DAN PEMBAHASAN}

Penelitian ini dilakukan sebanyak 16 kali pertemuan dari tanggal 27 april sampai 23 Mei 2017. Berikut adalah deskripsi data hasil kemampuan mengenal bangun datar pada anak cerebral palsy yang didapat selama fase baseline 1 (A-1), fase Intervensi (B), dan fase baseline 2 (A2). Indikator dalam mengenal bangun datar ini adalah menunjukkan bentuk bangun datar, menyebutkan bentuk bangun datar dan mengelompokkan bentuk bangun datar. Bangun datar yang diuji adalah bentuk bujur sangkar, lingkaran, persegi panjang dan segitiga.

Kondisi baseline 1 (A-1) dilakukan secara alamiah tanpa ada perlakuan/intervensi dari peneliti. Fase ini juga dilakukan sebelum adanya intervensi sebagai patokan bahwa hasil tersebut merupakan kemampuan awal anak dalam mengenal bangun datar. Berdasarkan pengamatan menunjukkan bahwa hasil baseline 1 (A-1) dari 4 sesi mendapat hasil yang sama yaitu 33,33 \%. Hal ini menunjukkan hasil yang stabil. Pada fase intervensi dilakukan sebanyak 8 sesi. Berdasarkan pengamatan pada sesi ke 5 diperoleh skor 6 dengan perolehan persentase $50 \%$, pada sesi ke 6 diperoleh skor 9 dengan perolehan persentase $75 \%$, 
pada sesi ke 7 masih dengan hasil yang sama yaitu $75 \%$, pada sesi ke 8 mengalami peningkatan dari skor 9 menjadi 10 dengan perolehan persentase $83,33 \%$, pada sesi ke 9 mengalami peningkatan lagi dari 10 menjadi 11 dengan perolehan persentase 91,67\%, pada sesi ke 10 meningkat lagi menjadi $100 \%$, pada sesi 11 diperoleh skor 11 dengan persentase 91,67\%. Dari sesi 10 ke 11 mengalami penurunan, hal itu kemungkinan disebabkan waktu itu subjek baru pulang dari study tour, sehingga terlihat lelah. Lalu pada sesi ke 12 tetap sama dengan skor 11 dan diperoleh persentase $91,67 \%$, kondisinya pada waktu itu anak baru saja bangun tidur dan ingin segera belajar lalu fase baseline 2 (A-2) dilakukan setelah adanya intervensi untuk kemampuan mengenal bangun datar. Fase ini dilakukan selama empat sesi, yang bertujuan untuk melihat hasil setelah diadakannya intervensi pada subjek. Berdasarkan pengamatan menunjukkan bahwa hasil baseline 1 (A1) dari 4 sesi mendapat hasil yang sama yaitu $100 \%$. Hal ini menunjukkan hasil yang stabil.

Berikut akan ditampilkan hasil perolehan anak pada kondisi baseline 1 (A1), Intervensi (B), dan baseline 2 (A2):

\section{Grafik 1}

Perolehan Data Baseline 1 (A1), Intervensi (B), dan Baseline 2 (A2) Kemampuan Mengenal bangun datar

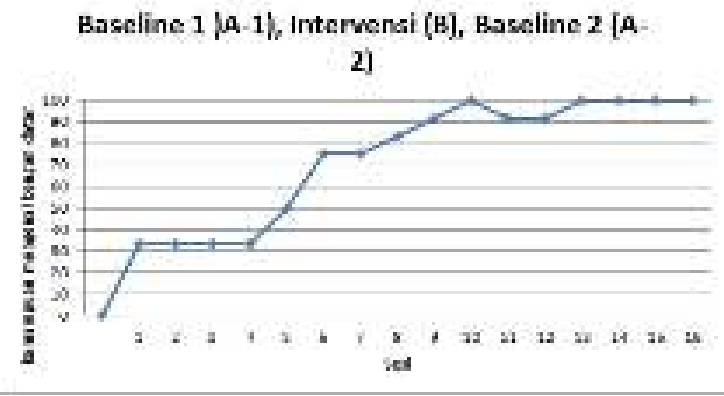

Panjang kondisi dalam penelitian ini adalah 4 sesi untuk kondisi baseline 1 (A1), untuk kondisi intervensi (B) selama 8 sesi dan 4 sesi untuk kondisi baseline 2 (A2). Kecenderungan arah baseline 1 (A-1) terlihat mendatar, untuk fase intervensi (B) kecenderungan arah menaik dan fase baseline 2 (A-2) kecenderungan arah mendatar. Kecenderungan stabilitas baseline 1 (A-1) adalah $100 \%$ (stabil), untuk intervensi (B) $37,5 \%$ (variabel) dan kondisi baseline 2 (A-2) $100 \%$ (stabil). Jejak data dalam penelitian ini mendatar pada baseline 1 (A-1), menaik untuk intervensi (B) dan mendatar kembali pada baseline 2 (A-2). Level stabilitas dan rentang pada kondisi baseline 1 (A-1) 33,33-33,33. Pada Intervensi 50-100 dan pada kondisi baseline 2 (A-2) yaitu 100100. Perubahan level pada kondisi baseline 1 (A-1) 33,3333,33(=). Pada intervensi 50-100 (+) dan pada kondisi Baseline 2 (A-2) yaitu 100-100 (=). Adapun rangkuman analisis visual dalam kondisi adalah sebagai berikut:

Tabel 1

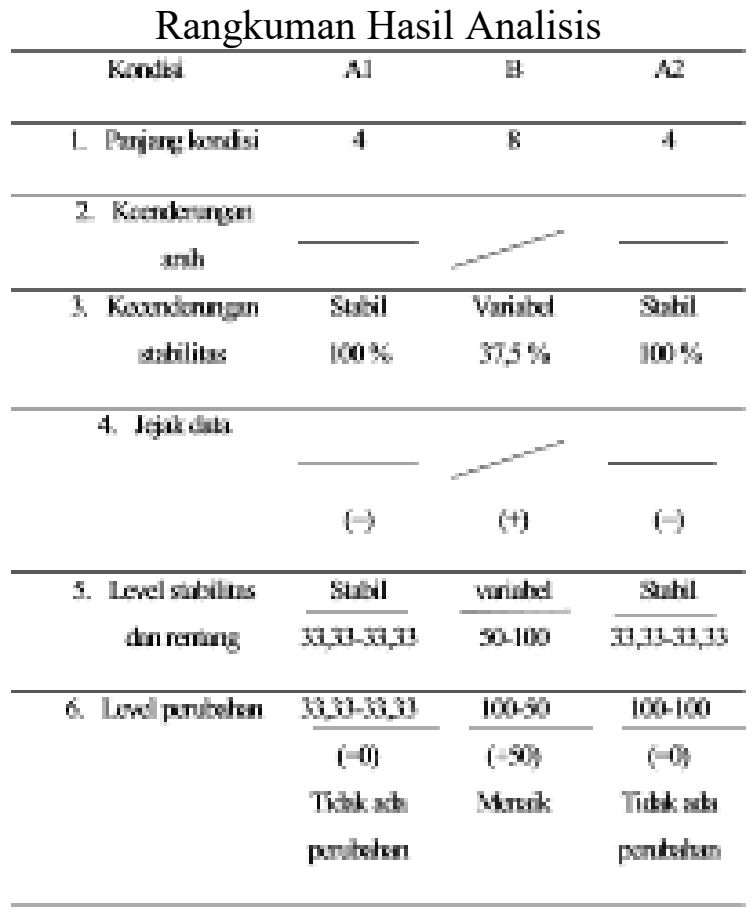


Hasil analisis antar kondisi yaitu terdiri dari jumlah variabel yang diubah, perubahan kecenderungan dan efeknya, perubahan stabilitas, perubahan level, dan mdata tumpang tindih (overlap). Jumlah variabel yang diubah pada kondisi baseline 1 (A-1) dengan kondisi intervensi (B) adalah 1:1. Kecenderungan arah pada baseline 1 (A-1) ke intervensi adalah mendatar ke menaik dan dari ntervensi (B) ke baseline 2 (A-2) adalah menaik ke mendatar. Perubahan kecenderungan stabilitasnya adalah variabel ke stabil dan stabil ke variabel. Perubahan level datanya A1/B adalah $(5033,33)=+16,67$ dan dari B/A2 adalah $(100-91,67)=+8,33$. Persentase overlap antar kondisi A1/B adalah $0 \%$ dan overlap antar kondisi B/A2 juga $0 \%$. Berikut rangkuman analisis visual antar kondisi dapat dilihat pada tabel di bawah ini.

Tabel 2

\begin{tabular}{|c|c|c|}
\hline $\begin{array}{l}\text { Kondis yous } \\
\text { diminguan }\end{array}$ & 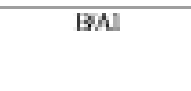 & A2B \\
\hline 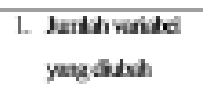 & 1 & 1 \\
\hline $\begin{array}{l}2 \text { Punhiles } \\
\text { haundrugen }\end{array}$ & $(+)$ & $H$ \\
\hline ardidandiburya & Manlat ke mua & Mbrik knaltex \\
\hline 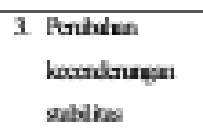 & 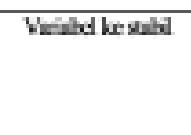 & Subal ke virialed \\
\hline 4. Pariahan koud & $\begin{array}{c}(50.3233) \\
+16,67\end{array}$ & $\begin{array}{c}(100-91,87) \\
+\mathbb{2}, 33\end{array}$ \\
\hline $\begin{array}{l}\text { 5. Prowlace } \\
\text { inulap }\end{array}$ & $0 \%$ & 8 \\
\hline
\end{tabular}

Subjek dalam penelitian ini mengalami hambatan cerebral palsy. Anak mengalami hambatan motorik ringan, kedua tangan anak sedikit kaku dan mampu berjalan secara pelan. Dalam kemampuan akademik menurut pendapat guru adalah sedikit delay. Ketika melakukan observasi, peneliti melihat kondisi anak yang pemalu, murung dan sesekali diejek oleh temannya. Peneliti menduga bahwa alasan anak tidak semangat belajar adalah disebabkan oleh faktor luar dan faktor dalam. Faktor dalam yang menyebabkan hambatan pada intelegensinya dan faktor luar yaitu kurangnya percaya diri, dan sikap pesimis. Hal ini sesuai dengan pendapat Salim (1996, hlm. 128) bahwa perilaku yang demikian, merupakan perwujudan dari reaksi emosional anak terhadap kondisinya. Secara psikologis perilaku ini juga sebagai ungkapan adanya pernyimpangan perilaku yang berhubungan dengan harga diri yang rendah, gangguan perilaku yang berhubungan dengan identitas yang kabur, serta gangguan perilaku yang berhubungan dengan depersonalisasi yang disebabkan oleh kelainannya.

Menurut hasil wawancara dengan guru anak belum memahami bangun datar, padahal hal itu sudah diajarkan di kelas. Setiap harinya anak memang terlihat murung dan harus dilihat oleh ibunya dari luar kelas. Tentunya, semangat dari dirinyalah yang sangat penting untuk masa depannya meskipun inteligensinya sedikit terhambat. Oleh karena itu anak membutuhkan metode atau media yang mampu menstimulasi berpikir serta memberikan rasa semangat kepada anak. Dengan metode VAKT diharapkan mampu meningkatkan kemampuan megenal bangun datar pada anak karena metode ini memiliki prinsip menyenangkan serta menggunakan seluruh indra anak.

Setelah melakukan penghitungan didapatkan bahwa hasil mean level pada kondisi baseline 1 (A-1) adalah 33,33 \%, untuk mean Intervensi (B) adalah 82,29 \% dan mean kondisi baseline 2 (A-2) adalah $100 \%$. Berdasarkan hasil dan penjelasan di atas, dapat disimpulkan bahwa latihan kemampuan mengenal bangun datar dengan metode VAKT berpengaruh baik dalam meningkatkan kemampuan mengenal bangun datar. Selain itu, untuk meningkatkan kemampuan mengenal bangun datar pada anak harus menggunakan media yang menarik perhatian 
anak serta pembelajarannya menyenangkan. Penelitian yang dilakukan ini membuktikan bahwa metode VAKT berpengaruh terhadap peningkatan kemampuan mengenal bangun datar pada anak cerebral palsy.

\section{E. SIMPULAN DAN SARAN}

Berdasarkan hasil penelitian dan analisis dalam kondisi dan antar kondisi kemampuan mengenal bangun datar (bujur sangkar, persegi panjang, lingkaran dan segitiga) pada EC dapat ditarik kesimpulan bahwa kemampuan anak dalam mengenal bangun datar sangat rendah sebelum diintervensi menggunakan metode VAKT. Hal ini bisa dilihat dari kondisi baseline 1 (A-1) yang dilakukan sebanyak 4 sesi mendapatkan hasil rata-rata 33,33 \%. Anak belum mampu menyebutkan bentuk bangun datar, anak mampu menunjukkan dan mengelompokkan beberapa bangun datar saja. Itupun subjek masih kesulitan dalam menjawab dan terlihat ragu-ragu. Setelah dilakukan intervensi pada subjek dengan metode VAKT, dan pelaksanaan metode ini menggunakan media yang menarik seperti bentuk kongkrit bangun datar dan media pasir fase baseline 2 (A-2) mengalami peningkatan yang sangat baik.

Kemampuan anak dalam menyebutkan, menunjukkan dan mengelompokkan bangun datar meningkat sangat baik yang ditunjukkan dengan hasil kondisi baseline 2 (A-2) yang mengalami peningkatan menjadi rata-rata 100 $\%$. Subjek mampu menjawab dengan penuh percaya diri tanpa ada keraguan, serta subjek merasa bahagia belajar mengenal bangun datar ini. Pengaruh metode vakt ini dapat dilihat dari perubahan level data antar kondisi pada baseline 1 (A-1) dengan fase baseline 2 (A-2), kemampuan mengenal bnagun datar pada subjek mengalami peningkatan sebesar $66,67 \%$. Selain itu, tidak ada data overlap atau data yang tumpang tindih yang menunjukkan bahwa metode VAKT sangat berpengaruh terhadap peningkatan kemampuan mengenal bangun datar pada anak cerebral palsy.
Dengan demikian metode VAKT ini terbukti dapat meningkatkan kemampuan mengenal bangun datar pada anak cerebral palsy.

\section{DAFTAR PUSTAKA}

Abdurrahman, Mulyono. (2003). Pendidikan Bagi Anak Berkesulitan Belajar. Jakarta: Rineka Cipta.

Afriyanti, Ana. (2016). Studi Kasus Pola Asuh Orang Tua Dalam Mengembangkan Kemandirian Bina Diri Anak Cerebral Palsy Tipe Spastik Di SLB Rela Bhakti 1 Gamping Sleman Yogyakarta. Jurnal Widia Ortodidaktika. 5 (7). Hlm. 739 751.

AHP, Utomo. (2013). Cerebral Palsy Tipe Spastic Diplegy Pada Anak Usia Dua Tahun. Jurnal Medula, 1 (4). Hlm. 25 34.

Delphie, Bandi. (2006). Pembelajaran Anak Berkebutuhan Khusus Dalam Setting Pendidikan Inklusi. Bandung: Refika Aditama.

Hermanto. (2006). Modifikasi Model Pembelajaran Bagi Anak Cerebral Palsy (Suatu Tantangan Kreativitas Guru). Majalah Ilmiah Pembelajaran. 2 (2). Hlm. 185-195.

Janah, Nurul. (2017). Penerimaan Diri Anak Cerebral Palsy (Studi Kasus Penerimaan Diri Anak Cerebral Palsy Yang Disebabkan Penyakit Toksoplasmosis. Jurnal Bimbingan dan Konseling. 6 (2). Hlm. 188-200.

Muh, Khairil Ichsan. (2014). Penatalaksanaan Fisioterapi pada Kasus Cerebral Palsy Spastic Athetoid Quadriplegi Di Pediatric And Neurodevelopmental Therapy Centre (PNTC). Laporan Penelitian. FIK-UMS. 
PEDAGOGIA : Jurnal Ilmu Pendidikan

Mulyono, Abdurrahman. (2012). Anak Berkesulitan Belajar. Jakarta: RINEKA CIPTA.

Nur Azizah. (2005). Meningkatkan Kemampuan Berkomunikasi Anak Cerebral Palsy. Jurnal Pendidikan Khusus. 1 (2). Hlm. 1-10.

Salim A. (1996). Pendidikan Bagi Anak Cerebral Palsy. Surakarta: DEPDIKBUD.

Mimin Tjasmini. (2016). Arah Pembelajaran Anak Cerebral Palsy. Pedagogia: Jurnal Ilmu Pendidikan. Hlm. 60-70.

Yusuf, Munawir. (2005). Pendidikan Bagi Anak Dengan Problema Belajar. Jakarta: Depdiknas. 